\title{
When should antiretroviral therapy be started in HIV-positive persons?
}

\author{
Caroline A Sabin
}

Address: Research Department of Infection and Population Health, Division of Population Health, UCL Medical School, Royal Free Campus, Rowland Hill Street, London NW3 2PF, UK

Email: c.sabin@ucl.ac.uk

FI000 Medicine Reports 2010, 2:8I (doi:I0.34I0/M2-8I)

This is an open-access article distributed under the terms of the Creative Commons Attribution-Non Commercial License (http://creativecommons.org/licenses/by-nc/3.0/legalcode), which permits unrestricted use, distribution, and reproduction in any medium, provided the original work is properly cited. You may not use this work for commercial purposes.

The electronic version of this article is the complete one and can be found at: http://fl000.com/reports/m/2/8I

\begin{abstract}
Recommendations for the initiation of combination antiretroviral therapy in HIV-positive individuals are largely based on data from observational studies. Whilst all guidelines recommend immediate treatment in individuals with a CD4 count of less than 350 cells $/ \mathrm{mm}^{3}$, guidelines vary in their recommendations for treatment at higher CD4 counts. Several large cohort studies have published findings that contribute to the debate, although conclusions vary and results from these studies may be subject to bias.
\end{abstract}

\section{Introduction and context}

In resource-rich settings, treatment guidelines are consistent in recommending the immediate initiation of combination antiretroviral therapy (cART) in all HIV-positive individuals with a CD4 count of less than 350 cells $/ \mathrm{mm}^{3}$; in this group, the benefits of cART clearly outweigh its disadvantages. However, there is inconsistency between the guideline committees as to whether asymptomatic individuals with $\mathrm{CD} 4$ counts equal to or greater than 350 cells $/ \mathrm{mm}^{3}$ should begin cART. For example, whilst the 2009 US Department of Health and Human Services guidelines [1] and the International AIDS Society-USA [2] panel recommend treatment for all patients with a CD4 count of 350-500 cells $/ \mathrm{mm}^{3}$, neither the European AIDS Clinical Society [3] nor the British HIV Association [4] recommends treatment at this level unless specific comorbidities are present. This inconsistency largely results from the limited evidence base; as only limited data are available from randomized trials on the benefits or risks of earlier cART [5], guideline committees have based their recommendations on evidence from observational studies and expert clinical opinion.

Until recently, the main arguments for delaying cART related to the toxicities and inconvenience of the drugs, as well as the concern that patients would be unable to maintain the high levels of adherence necessary to ensure sustained virological suppression. Little was felt to be gained from initiating cART in individuals with CD4 counts of greater than 350 cells $/ \mathrm{mm}^{3}$ in whom the risk of AIDS and consequent mortality was low. However, antiretroviral drugs are now more potent, have fewer toxicities, and are more forgiving to lapses in adherence. Furthermore, death rates in HIV-positive individuals remain elevated compared to those in the general population $[6,7]$ and it is believed that HIV may play a role in the development of several serious non-AIDS conditions [8-10]. Thus, cART may have a greater positive impact on the health of HIV-positive individuals than anticipated, which may now justify its earlier use. This review briefly summarises the latest evidence on the topic; recent reviews discuss some of the issues in more detail $[11,12]$.

\section{Recent advances}

Many observational studies have compared outcomes among individuals initiating cART at different CD4 counts $[13,14]$. However, an individual who is not diagnosed with HIV until his/her CD4 count has fallen to a low level could not have received treatment at a higher CD4 count 
(as s/he had not been diagnosed) but must have survived long enough to be diagnosed at the lower CD4 count. Failure to take account of this 'lead-time' may result in biased estimates of the benefits of early treatment [15]. Conclusions from early studies that used appropriate methodology to remove the effect of lead-time bias were inconsistent regarding the initiation of CART at a CD4 count of greater than 350 cells $/ \mathrm{mm}^{3}[16,17]$. However, these studies were relatively small, and the methods may not have been optimal.

Investigators from the North American AIDS Cohort Collaboration on Research and Design (NA-ACCORD) study [18] identified individuals who had experienced a CD4 count of either $351-500$ cells $/ \mathrm{mm}^{3}$ or greater than 500 cells $/ \mathrm{mm}^{3}$; these groups were then divided again into those who initiated cART immediately and those who deferred its use. The authors used inverse probability weighting methods to control for biases resulting from informative censoring (which may arise if patients who dropped out of the analysis at any stage had different characteristics to those who did not) and known confounders. Of the 67,527 patients in the study, 8362 had a CD4 count of $351-500$ cells $/ \mathrm{mm}^{3}$ (2084 initiated cART immediately) and 9155 a CD4 count of greater than 500 cells $/ \mathrm{mm}^{3}$ (2220 initiated cART immediately). Death rates were increased by $69 \%$ and $94 \%$, respectively, among those who deferred therapy in each group compared to those who started cART immediately. Investigators from the When to Start Consortium [19] considered progression to AIDS and/or death in 24,444 antiretroviral-naive individuals starting cART. Using information from 21,247 patients followed in the pre-cART era, the authors estimated the distribution of lead-times, which was then incorporated into the analysis. Deferred initiation of cART was generally associated with more rapid progression rates than immediate initiation, although the difference was not statistically significant at CD4 counts of greater than 350 cells $/ \mathrm{mm}^{3}$. Shepherd et al. [20] directly estimated the optimal CD4 count at which to initiate cART. Using a similar method to the NA-ACCORD group, they concluded that the optimal CD4 count depended on whether the ultimate aim of CART was to improve the patient's health (defined by an increase in the CD4 count or reduction in the occurrence of new AIDS events or death), in which case the threshold was between 489 and 554 cells $/ \mathrm{mm}^{3}$, or to improve quality-of-life, in which case the threshold was between 337 and 475 cells $/ \mathrm{mm}^{3}$. Most recently, Jonsson Funk et al. [21] presented data from the CASCADE Collaboration [21] suggesting that whilst the initiation of CART at a CD4 count of 350-500 cells $/ \mathrm{mm}^{3}$ may reduce the risk of clinical progression, the low absolute risk of progression meant that 34 patients would need to be treated to prevent one new case of AIDS or death (or 71 patients for death only) over a three-year period.

As an alternative approach, several authors have used computer simulation models to address the issue. Mauskopf et al. [22] estimated that initiation of cART at a CD4 count of greater than 350 cells $/ \mathrm{mm}^{3}$ would result in longer quality-adjusted survival compared to starting cART at lower CD4 counts. Braithwaite et al. [23] demonstrated that treatment at a CD4 count of 500 cells $/ \mathrm{mm}^{3}$ resulted in gains in quality-adjusted life-years at all ages, even assuming that patients may not be fully adherent to cART. The validity of results from modelling studies does, however, rely strongly on the assumption that the model accurately describes disease progression.

\section{Implications for clinical practice}

Whilst the accruing evidence would suggest that earlier initiation of cART may be beneficial, one limitation of all observational studies is that of unmeasured confounding. Under most treatment guidelines, few patients initiate cART at high CD4 counts and those who do may differ from those who do not in terms of their likely long-term outcomes, regardless of cART use. It is unlikely that any observational study will be able to fully control for these differences. Even if shown to be beneficial, the full 'costs' (financial or other) of earlier cART must be assessed. At least one randomised trial of earlier versus deferred cART is underway [24] and it would be prudent to wait for the results of this before changing guidelines. Finally, whilst the decision to initiate cART is predominantly based on an individual's CD4 count, other biomarkers [25-27] may also provide information about an individual's risk of clinical events; incorporation of these biomarkers into the decision-making process may further optimise the timing of cART in individual patients.

\section{Abbreviations}

AIDS, acquired immune deficiency syndrome; cART, combination antiretroviral therapy; HIV, human immunodeficiency virus; NA-ACCORD, North American AIDS Cohort Collaboration on Research and Design.

\section{Competing interests}

The author reports that several colleagues are actively involved in the design and management of the Strategic Timing of Antiretroviral Treatment (START) trial.

\section{References}

I. DHHS Panel on Antiretroviral Guidelines for Adults and Adolescents: Guidelines for the Use of Antiretroviral Agents in HIV-I-Infected Adults and Adolescents. Bethesda, MD, USA: Department of Health and Human 
Services; 2009, I-I6I. [http://aidsinfo.nih.gov/contentfiles/AdultandA dolescentGL.pdf]

2. Thompson MA, Aberg JA, Cahn P, Montaner JSG, Rizzardini G, Telenti A, Gatell JM, Günthard HF, Hammer SM, Hirsch MS, Jacobsen DM, Reiss P, Richman DD, Volberding PA, Yeni P, Schooley RT; International AIDS Society-USA: Antiretroviral treatment of adult HIV infection: 2010 recommendations of the International AIDS Society-USA panel. JAMA 2010, 304:32|-33.

3. Clumeck N, Pozniak A, Raffi F; EACS Executive Committee: European AIDS Clinical Society (EACS) guidelines for the clinical management and treatment of HIV-infected adults. HIV Med 2008, 9:65-7I. [http://europeanaidsclinicalsociety.org/guidelinespdf/I_Treatment_of_HIV_Infected_Adults.pdf]

4. Gazzard BG, Anderson J, Babiker A, Boffito M, Brook G, Brough G, Churchill D, Cromarty B, Das S, Fisher M, Freedman A, Geretti AM, Johnson M, Khoo S, Leen C, Nair D, Peters B, Phillips A, Pillay D, Pozniak A, Walsh J, Wilkins E, Williams I, Williams M, Youle M; BHIVA Treatment Guidelines Writing Group: British HIV Association Guidelines for the Treatment of HIV-I-Infected Adults with Antiretroviral Therapy. HIV Med 2008, 9:563-608.

5. Severe P, Juste MA, Ambroise A, Eliacin L, Marchand C, Apollon S, Edwards A, Bang H, Nicotera J, Godfrey RM, Johnson WD, Pape JW, Fitzgerald DW: Early versus standard antiretroviral therapy for HIV-infected adults in Haiti. N Engl J Med 20I0, 363:257-65.

FI000 Factor 8

Evaluated by Anthony Harries 09 Sep 2010

6. Study Group on Death Rates at High CD4 Count in Antiretroviral Naive Patients, Lodwick RK, Sabin CA, Porter K, Ledergerber B, van Sighem A, Cozzi-Lepri A, Khaykin P, Mocroft A, Jacobson L, De Wit S, Obel N, Castagna A, Wasmuth JC, Gill J, Klein MB, Gange S, Riera M, Mussini C, Gutiérrez F, Touloumi G, Carrieri P, Guest JL, Brockmeyer $\mathrm{NH}$, Phillips $\mathrm{AN}$ : Death rates in HIV-positive antiretroviral-naive patients with CD4 count greater than 350 cells per microL in Europe and North America: a pooled cohort observational study. Lancet 2010, 376:340-45.

7. Bhaskaran K, Hamouda O, Sannes M, Boufassa F, Johnson AM, Lambert PC, Porter K; CASCADE Collaboration: Changes in the risk of death after HIV seroconversion compared with mortality in the general population. JAMA 2008, 300:5I-9.

FI000 Factor 8

Evaluated by Eric Daar 18 Jul 2008

8. Phillips AN, Neaton J, Lundgren JD: The role of HIV in serious diseases other than AIDS. AIDS 2008, 22:2409-I8.

9. Data Collection on Adverse Events of Anti-HIV Drugs (D:A:D) Study Group, Smith C: Factors associated with specific causes of death amongst HIV-positive individuals in the D:A:D Study. AIDS 2010, 24:1537-48.

10. Strategies for Management of Antiretroviral Therapy (SMART) Study Group, Emery S, Neuhaus JA, Phillips AN, Babiker A, Cohen C], Gatell JM, Girard PM, Grund B, Law M, Losso MH, Palfreeman A, Wood R: Major clinical outcomes in antiretroviral therapy (ART)-naive participants and in those not receiving ART at baseline in the SMART Study. J Infect Dis 2008, I 97: I 133-44.

FI000 Factor 8

Evaluated by Eric Daar 06 May 2008

II. Jain V, Deeks SG: When to start antiretroviral therapy. Curr HIVI AIDS Rep 2010, 7:60-8.

12. Sabin CA: Early antiretroviral therapy: the role of cohorts. Curr Opin HIV AIDS 2009, 4:200-5.

13. May M, Sterne JA, Sabin C, Costagliola D, Justice AC, Thiébaut R, Gill J, Phillips A, Reiss P, Hogg R, Ledergerber B, D'Arminio Monforte A, Schmeisser N, Staszewski S, Egger M; Antiretroviral Therapy (ART) Cohort Collaboration: Prognosis of HIV-Iinfected patients up to 5 years after initiation of HAART: collaborative analysis of prospective studies. AIDS 2007, 2 I: I | 85-97.
14. HIV-CAUSAL Collaboration: The effect of combined antiretroviral therapy on the overall mortality of HIV-infected individuals. AIDS. 2010, 24:123-37.

15. Cole SR, Li R, Anastos K, Detels R, Young M, Chmiel JS, Muñoz A: Accounting for leadtime in cohort studies: evaluating when to initiate HIV therapies. Stat Med 2004, 23:335I-63.

16. Cole SR, Hernán MA, Anastos K, Jamieson BD, Robins JM: Determining the effect of highly active antiretroviral therapy on changes in human immunodeficiency virus type I RNA viral load using a marginal structural left-censored mean model. Am J Epidemiol 2007, 166:219-27.

17. Jaén A, Esteve A, Miró JM, Tural C, Montoliu A, Ferrer E, Riera M, Segura F, Force L, Sued O, Vilaró J, Garcia I, Masabeu A, Altès J, Coltet B, Podzamczer D, Murillas J, Navarro G, Gatell JM, Casabona J; PISCIS Study Group: Determinants of HIV progression and assessment of the optimal time to initiate highly active antiretroviral therapy. I Acquir Immune Defic Syndr 2008, 47:21 2-20.

18. Kitahata MM, Gange SJ, Abraham AG, Merriman B, Saag MS, Justice AC, Hogg RS, Deeks SG, Eron JJ, Brooks JT, Rourke SB, Gill MJ, Bosch RJ, Martin JN, Klein MB, Jacobson LP, Rodriguez B, Sterling TR, Kirk GD, Napravnik S, Rachlis AR, Calzavara LM, Horberg MA, Silverberg MJ, Gebo KA, Goedert J], Benson CA, Collier AC, Van Rompaey SE, Crane HM, et al.; NA-ACCORD Investigators: Effect of early versus deferred antiretroviral therapy for HIV on survival. N Engl J Med 2009, 360:I8I5-26.

FI000 Factor 14

Evaluated by Kiat Ruxrungtham 09 Feb 2010, Jason Brenchley 28 Apr 2009, Anthony Harries 05 May 2009

19. When to Start Consortium, Sterne JA, May M, Costagliola D, de Wolf F, Phillips AN, Harris R, Funk MJ, Geskus RB, Gill J, Dabis F, Miró JM, Justice AC, Ledergerber B, Fätkenheuer G, Hogg RS, Monforte AD, Saag M, Smith C, Staszewski S, Egger M, Cole SR: Timing of initiation of antiretroviral therapy in AIDS-free HIV-I-infected patients: a collaborative analysis of I 8 HIV cohort studies. Lancet 2009, 373:1352-63

20. Shepherd BE, Jenkins CA, Rebeiro PF, Stinnette SE, Bebawy SS, McGowan CC, Hulgan T, Sterling TR: Estimating the optimal CD4 count for HIV-infected persons to start antiretroviral therapy. Epidemiology 2010, 21:698-705.

21. Jonsson Funk M, Fusco JS, Cole SR, Thomas JC, Porter K, Kaufman JS, Davidian M, White AD, Hartmann KE, Eron J]; CASCADE Collaboration: HAART initiation and clinical outcomes: insights from the CASCADE cohort of HIV-I seroconverters on 'When to Start'. Presented at XVIII International AIDS Conference; I8-23 July 2010; Vienna, Austria. [http://pag.aids20I0. org/Abstracts.aspx?AID= 16875$]$

22. Mauskopf J, Kitahata M, Kauf T, Richter A, Tolson J: HIV antiretroviral treatment: early versus later. J Acquir Immune Defic Syndr 2005, 39:562-9.

23. Braithwaite RS, Roberts MS, Bidwell Goetz M, Gibert CL, RodriguezBarradas MC, Nucifora K, Justice AC: Do benefits of earlier antiretroviral treatment initiation outweigh harms for individuals at risk for poor adherence. Clin Infect Dis 2009, 48:822-6.

FI000 Factor 6

Evaluated by Caroline Sabin 14 Apr 2009

24. Phillips AN, Emery S: Predicting the potential benefits of early initiation of ART: time to do a trial to find out. Curr Opin HIV AIDS 2009, 4:165-6.

25. Harris RJ, Sterne JA, Abgrall S, Dabis F, Reiss P, Saag M, Phillips AN, Chene G, Gill JM, Justice AC, Rockstroh J, Sabin CA, Mocroft A, Bucher HC, Hogg RS, Monforte AD, May M, Egger M; Antiretroviral Therapy Cohort Collaboration: Prognostic importance of anaemia in HIV type-I-infected patients starting antiretroviral therapy: collaborative analysis of prospective cohort studies. Antivir Ther 2008, I 3:959-67.

26. Rodger AJ, Fox Z, Lundgren JD, Kuller LH, Boesecke C, Gey D, Skoutelis A, Goetz MB, Phillips AN; INSIGHT Strategies for 
Management of Antiretroviral Therapy (SMART) Study Group: Activation and coagulation biomarkers are independent predictors of the development of opportunistic disease in patients with HIV infection. J Infect Dis 2009, 200:973-83.

FI000 Factor 6

Evaluated by Eric Daar 24 Nov 2009
27. Justice AC, McGinnis KA, Skanderson M, Chang CC, Gibert CL, Goetz MB, Rimland D, Rodriguez-Barradas MC, Oursler KK, Brown ST, Braithwaite RS, May M, Covinsky KE, Roberts MS, Fultz SL, Bryant KJ; VACS Project Team: Towards a combined prognostic index for survival in HIV infection: the role of 'non-HIV' biomarkers. HIV Med 2010, II: $|43-5|$. 